DOI: https://doi.org/10.24127/ajpm.v100i2.3600

\title{
WHAT ARE THE TYPE OF LEARNING MEDIA INNOVATION NEEDED TO SUPPORT DISTANCE LEARNING?
}

\author{
Agus Hendriyanto $^{1^{*}}$, Tri Atmojo Kusmayadi ${ }^{2}$, Laila Fitriana ${ }^{3}$ \\ $1^{1 * 2,3}$ Universitas Sebelas Maret, Surakarta, Indonesia \\ * Corresponding author. Jalan Ir. Sutami 36 Kentingan, Jebres, Surakarta, Jawa Tengah, Indonesia 57126 \\ E-mail: $\quad$ agushendriyanto@student.uns.ac.id $^{1)}$ \\ $\underline{\text { tri.atmojo.kusmayadi@staff.uns.ac.id }}^{2)}$ \\ lailafitriana_fkip@staff.uns.ac.id ${ }^{3)}$
}

Received 04 March 2021; Received in revised form 17 June 2021; Accepted 28 June 2021

\begin{abstract}
This exploratory qualitative article with an inductive approach aims to analyze the needs of students of the mathematics education study program at one of the leading universities in Surakarta City regarding learning media that can facilitate the implementation of distance learning during the Coronavirus pandemic. Data were obtained through distributing questionnaires using Google Form to 63 students who had taken the analytic geometry course at the beginning of the Coronavirus pandemic, interviews with 2 lecturers, and 3 students selected through snowball sampling technique. The results of the analysis showed that students need interactive audio-visual teaching materials that can be accessed easily without any internet network constraints. It is evidenced by the results of the survey which show that $70 \%$ of students need audio-video-based learning media. The results of this study become the basis for developing learning media that supports the implementation of distance learning
\end{abstract}

Keywords: Analytic geometry; learning media; coronavirus pandemic; distance learning.

\begin{abstract}
Abstrak
Artikel kualitatif eksploratif dengan pendekatan induktif ini disusun dengan tujuan untuk menganalisis kebutuhan mahasiswa program studi pendidikan matematika di salah satu universitas ternama di Kota Surakarta terkait media pembelajaran yang dapat mempermudah pelaksanaan pembelajaran jarak jauh selama masa pandemi virus corona. Data diperoleh melalui pendistribusian angket dengan Google Form kepada 63 mahasiswa yang telah menempuh mata kuliah geometri analitik bidang di awal terjadinya pandemi virus corona, wawancara dengan 2 dosen, dan 3 mahasiswa yang dipilih melalui teknik snowball sampling. Hasil analisis menunjukkan bahwa mahasiswa membutuhkan bahan ajar interaktif berbasis audio-visual yang dapat diakses dengan mudah tanpa adanya kendala jaringan internet. Hal ini dibuktikan dengan hasil survey yang menunjukkan bahwa 70\% mahasiswa memerlukan media pembelajaran elektronik berbasis audio-video. Hasil penelitian ini digunakan sebagai dasar untuk mengembangkan media pembelajaran yang mendukung pelaksanaan pembelajaran jarak jauh.
\end{abstract}

Kata kunci: Geometri analitik; media pembelajaran; pandemi virus corona; pembelajaraan jarak jauh.

This is an open access article under the Creative Commons Attribution 4.0 International License

\section{INTRODUCTION}

At the end of 2019, the world was shocked by a pandemic that occurred in Wuhan City, Hubei Province, Republic of China, where a series of reports about strange pneumonia emerged among its inhabitants (Nkansah et al., 2020).
Pneumonia due to the coronavirus has started to spread globally and rapidly (Rusmini et al., 2020) and has become a health disaster in almost all countries in the world, including Indonesia (Saputro et al., 2020). This condition does not only affect the health aspect but also all 
aspects of life including academic activities (Tsitsia et al., 2020). Since the WHO announces it as a Global Pandemic, there has been a paradigm shift (Sy et al., 2020) from direct (faceto-face) learning to online learning (Elearning) in all educational institutions (Tsitsia \& Kabbah, 2020). The Coronavirus continues spreading and what can be done now is prevention, for example implementing online learning (Mulenga \& Marbán, 2020).

In Indonesia, online learning is considered the best approach to continue teaching and learning activities during the Coronavirus pandemic (Mailizar et al., 2020). In its implementation, online learning requires educators and students to only be connected virtually (Radha et al., 2020) and it causes new problems in the learning process. Based on the results of interviews with lecturers and students of the mathematics education study program at one of the leading universities Surakarta City, Indonesia, the problems of online learning covers the lack of learning resources, poor internet access, and the number of assignments given by lecturers. Jayalath et al. (2020) revealed that online learning requires students to be more independent learners. Therefore, the role of learning media becomes vital.

Some researchers have developed instructional media and learning models to overcome this problem (Kerres, 2020; Peters et al., 2020; Zhu \& Liu, 2020). Distance learning (e-learning) is needed in industrial revolution 4.0 (Arizona, 2020). Moreover, higher education at the university level should have implemented a mixed learning model, namely face-to-face learning and online learning typically known as called blended-learning (Gopal \& Venugopal, 2020). This pandemic is the best time to innovate in online learning by compiling simple, precise, and accurate schemes even without face-toface learning as usual (Septyanti \& Kurniawan, 2020).

One of the prominent characteristics of the current era is the development of science and technology affecting all aspects of life globally. The advanced development of information technology has dominated every aspect of life. Information technology has a key role in business activities, organizational structure changes, and organizational management. Further, information technology also highly affects scientific development and becomes the main tool in an academic institution. Currently, there is a paradigm shift or way of thinking in dealing with various phenomena, including in education.

Educators and students are the main elements in education. In the learning process, educators play an important role to achieve the learning objective. They also play a key role in the implementation of the learning process. Even though educators have the intelligence and ability to teach, the learning process will be boring and less attractive for students without being supported by appropriate learning media, particularly in mathematics learning which is still considered a scary and boring subject.

During this pandemic, lecturing has to be carried out without direct physical contact between students and lecturers to prevent transmission of the Coronavirus virus (Firman \& Rahayu, 2020). Therefore, the use of digital technology is a must in implementing distance learning during the pandemic. The use of technology in education or refers to e-learning (Farman \& Chairuddin, 2020). 
DOI: https://doi.org/10.24127/ajpm.v100i2.3600

Currently, one of the courses that are facing challenges is the analytic geometry course. Analytic geometry is a combination of geometry and algebra, meaning that geometric problems are solved using algebra (or analytically). Analytical geometry is the study of geometric objects using a coordinate system which is reviewed using the concepts and principles of algebra and analysis. Indeed, it is difficult to understand analytic geometry only through self-learning. Besides, during this pandemic, the design of learning components has not been optimal.

In terms of media, the media used was limited to audiovisuals media downloaded from YouTube and/or using integrated online materials provided by lecturers. The evaluation is limited to material testing without the interaction of students in presentation as usual. If not, the material is only delivered by a pdf document.

A previous study about analysis of the need for learning media at the higher education was conducted by Maharani (2021) which focused on anaysis of the need for teaching materials in calculus course. The study was limited to certain subjects and no in-depth study regarding the type of media needed by the students.

This research is considered necessary as with a needs analysis, there will be a follow-up in the form of the creation of learning innovations at the university level as an alternative to support the implementation of distance learning during the pandemic to make learning effective and also maintain the achievement of the competencies.

This study aims to analyze the needs of students in the mathematics education study program related to learning media to increase students' understanding of the analytic geometry.

\section{METHOD}

Research Design

This qualitative research used a case study design. The cases were the challenges and problems of lecturers and students in implementing distance learning during the pandemic as well as the innovation needed.

This present study was conducted in regards to the pandemic and the implementation of distance learning. Then the researchers interviewed some lecturers and students to find out the problems. Then, the researcher distributed the questionnaire to identify the needs of the media.

This study used a qualitative inductive exploratory method. This method is to explore broadly and deeply the causes or things that influence a certain phenomenon. The exploratory design was selected as it can investigate the complex patterns of the experiences of the individuals and groups involved (Bhattacharyya et al., 2020). Besides, qualitative data collection methods can investigate more about the challenges and problems of lecturers and students in implementing distance learning during the Coronavirus pandemic as well as the innovation needed.

\section{Research Participants}

This study involved 63 students of the mathematics education study program of a university in Surakarta City. The participants were taken randomly from 250 students who had taken distance learning for analytic geometry courses. Besides, 3 subjects of interviews were selected using snowball sampling. Further, 2 lecturers of analytic geometry course during this pandemic were also interviewed.

\section{Research Instruments}

The instrument in this research was questionnaires and interview 
guidelines. The questionnaire was compiled and discussed in an onlinefocused group discussion (FGDOnline). The questionnaire consisted of 30 questions addressed to students. Interview guidelines became the reference in conducting interviews with research subjects.

\section{Data Collection and Analysis}

Data collection was conducted online. Online surveys are used due to their compatibility and flexibility with the demand for online learning during a pandemic (Irfan et al., 2020). Further, online surveys are easy to manage and access at any time using multiple devices (Sunhare et al., 2020). The questionnaire was distributed after the validity was tested by three experts in learning from two famous universities in Surakarta. Moreover, the questionnaire was in Google Form and the link was distributed through the students' WhatsApp group in June 2020. The questionnaire was available for one week and after completing the form, the respondent got the results. Interviews were done using the video calls feature of Telegram.

Then, the obtained data were analyzed using the thematic analysis technique. The thematic analysis is to identify important or interesting themes from the results of the questionnaire (Xu \& Zammit, 2020). The results of the analysis of the questionnaire were then supported with the results of the interviews.

\section{RESULTS AND DISCUSSION}

The results showed that the implementation of distance learning was through some platforms, including Schoology, WhatsApp Group, and Google. The questionnaire and interview analysis resulted in two main themes or topics, namely problems in learning and the need for learning innovation.

\section{Problems in Learning}

Blended-learning should have become a common practice in this industrial revolution 4.0 (Setiawan, 2019). Learning that combines conventional learning or face-to-face classrooms and online learning (Chango et al., 2021) should have become a common practice. However, the implementation of online learning during this pandemic still faces many challenges.

Online learning is learning that uses an internet-based interactive model and a Learning Management System (LMS) (Mishra et al., 2020). Learning programs organized in a network can be carried out synchronously and asynchronously (Nieuwoudt, 2020). Synchronous learning is learning that is carried out directly by lecturers and students in the classroom with the help of technology (Chen et al., 2020). Meanwhile, asynchronous learning emphasizes students learning independently within a certain time using materials in the form of handouts, audio/video lectures, PowerPoint presentations, and articles that can be accessed at any time (Amiti, 2020).

The results of the questionnaire and interview analysis showed that distance learning is less effective than face-to-face learning due to the following reasons. First, the content of the material delivered by lecturers via online both synchronous and asynchronous learning may not be fully understood by all students. It is because the content is only presented in the pdf or PowerPoint file per meeting. Sometimes the lecturers make learning videos then upload them to YouTube 
enabling students to access them at any time. Indeed, the material can be understood by students, but their understanding is not comprehensive. They understand based on their own interpretation or point of view only as many students provide the wrong answer for assignments or quizzes are given. Faize \& Nawaz (2020) state that the lack of interaction between students and lecturers is an obstacle to the learning process. A lecturer said, "I can't interact with students as I did during the normal day so that the material that should be maximally conveyed becomes more difficult to understand."

Second, lecturers have tried their best to provide the best learning during this pandemic. However, the lecturers' ability in utilizing technology in online learning is limited. It cannot be denied that technology has developed rapidly, but the limited human resources that can utilize this technology have made the existing technology less optimal. Some technology is available for online learning, but sometimes they create a lot of difficulties for lecturers (Dhawan, 2020). The difficulties cover download errors, installation problems, login problems, problems with audio and video, etc. One of the lecturers said, "Besides serving questions and answers via WhatsApp and discussions in Schoology, I also made learning videos and I uploaded them on my YouTube channel so that students can repeatedly watching my explanations."

Third, lecturers have difficulty in controlling the implementation of online learning. "I can't force students to always be on camera during the lectures because when the camera is on, it will reduce students' mobile data more," said a lecturer. Many students do not use it. Even, some students at the beginning of learning fill out the attendance list, then they are no longer active until the learning time is over. Maybe they do other activities. However, many students are active until the lesson is over and some are active but not fully until the end of the lesson. It is different from Zaheer \& Munir (2020) who argued that "if a lecturer considers monitoring remote learning is a difficult task, they tend not to motivate their students."

Then, based on the student factor, the problems covered: First, students are less active and interested in participating in online learning even though they are supported by adequate facilities such as computers, cellphones/ gadgets, and internet networks. However, some students in rural areas have poor internet networks. Research conducted by Zuriah \& Rahmandani (2021) found that the first obstacle in online learning is the poor network or internet connection, especially during bad weather. It hampered the online learning process (Verma et al., 2020). A student got bored with online learning saying "I think that distance learning is very ineffective and makes me even more tired."

Second, learning resources are limited. Most students only rely on learning resources provided by the lecturer in the form of pdf/PowerPoint files and not all lecturers can make instructional videos. The instructional videos can be uploaded on YouTube so that students need an internet network to access them. On the other hand, students previously could find printed books from the library, but now they have difficulties in finding printed resources (Rahmawati \& Khamid, 2020). A student said, "I don't have reference books that are easy to understand when studying independent- 
DOI: https://doi.org/10.24127/ajpm.v100i2.3600

ly like today. I think I need assistance from the lecturers to be able to understand them."

Third, students take a lot of courses, and all courses give assignments. Sometimes students feel tired from doing the assignments. This results in less effective learning in which students only rely on their friends' work who have good academic achievement. "Sometimes, some of the lecturers in other subjects gave excessive assignments, it makes me tired and finally I can't focus on the analytic geometry course," said a student in an interview.

\section{Innovation Needed}

Mathematics learning during distance learning in tertiary institutions requires quality improvement in various aspects such as preparation, learning materials, and learning methods, facilities and infrastructure to achieve the desired learning goals (Kamsurya, 2020). The results of the analysis showed that students need interactive audio-visual materials that can be accessed easily without any internet network constraints. It is evidenced by the survey results which showed that $70 \%$ of students need audio-video-based learning media.

The positive response of educators and students to the effectiveness of video-based learning media helps educators and students to improve the competencies that should be achieved (Budiastra et al., 2020).

In summary, the findings of this study are: 1) the content of material delivered by lecturers in the online learning may not be fully understood by all students, both synchronous and asynchronous learning, 2) limited learning resources for students, 3) students' learning burden increases compared to in conventional learning, and 4) students need digital-based learning multimedia that can support online learning.

Indeed, the study shows that distance learning is new and suddenly they have to apply it. This study can be used as a basis for researchers to develop learning media, but it's only limited to one study program.

The results of this study are in line with the study conducted by Septyanti \& Kurniawan (2020) in which students need audio learning materials in the form of narrated voices to train and test listening skills only. Then, students also need to listen and watch videos to train and test their overall listening skills.

The follow-up of this study is the development of learning media to supports students' activities in learning, especially in the online learning process. It is important because no one knows how long this pandemic will end. Even if the pandemic has ended, it is time for education to only digital learning besides conventional learning.

\section{CONCLUSION AND SUGGESTION}

Distance learning has to be continued to anticipate no child left behind in education. It is difficult to be able to achieve effective learning as normal learning before the Covid-19 pandemic through distance learning. Therefore, it is necessary to have learning innovations that must be continuously developed according to environmental conditions.

Limited learning resources and poor internet access become fundamental problems for some students. Based on the results of the analysis, it is necessary to develop digital materials with visualization and detailed explanation that does not require an internet network to access. 
DOI: https://doi.org/10.24127/ajpm.v100i2.3600

It is expected that the developed teaching materials that support distance learning can be used in normal conditions to support the implementation of blended-learning.

\section{REFERENCE}

Amiti, F. (2020). European Journal of Open Education and E-learning Studies Synchronous and Asynchronous E-Learning. European Journal of Open Education and E-Learning Studies, 5(2), 60-70. https://doi.org/10.46827/ejoe.v5i2 .3313

Arizona, K. (2020). Elevating Students' Competence Based Ict in the Era of Industrial Revolution 4.0. Journal of Teaching and Learning Physics, 5(2), 48-59. https://doi.org/10.15575/jotalp.v5i 2.7987

Bhattacharyya, D. S., Shafique, S., Akhter, S., Rahman, A., Islam, M. Z., Rahman, N., \& Anwar, I. (2020). Challenges and Facilitators of Implementation of An Information Communication and Technology (ICT)-based Human Resources Management Tool in The Government Health Sector in Bangladesh: Protocol for An Exploratory Qualitative Research Study. BMJ Open, 10(12), 1-7. https://doi.org/10.1136/bmjopen2020-043939

Budiastra, A. A. K., Wicaksono, I., \& Erlina, N. (2020). The effectiveness of video-based interaction on professional science teachers to improve elementary school students achievements. Journal for the Education of Gifted Young Scientists, 8(3), 1291-1304.
https://doi.org/10.17478/JEGYS.7 15139

Chango, W., Cerezo, R., \& Romero, C. (2021). Multi-Source and Multimodal Data Fusion for Predicting Academic Performance in Blended Learning University Courses. Computers and Electrical Engineering, 106908(89), 1-13. https://doi.org/10.1016/j.compelec eng.2020.106908

Chen, E., Kaczmarek, K., \& Ohyama, H. (2020). Student Perceptions of Distance Learning Strategies During COVID-19. Journal of Dental Education, 1-2. https://doi.org/10.1002/jdd.12339

Dhawan, S. (2020). Online Learning: A Panacea in the Time of COVID19 Crisis. Journal of Educational Technology Systems, 49(1), 5-22. https://doi.org/10.1177/00472395 20934018

Faize, F. A., \& Nawaz, M. (2020). Evaluation and Improvement of Students' Satisfaction in Online Learning During COVID-19. Open Praxis, 12(4), 495-507. https://doi.org/10.5944/openpraxis .12.4.1153

Farman, \& Chairuddin. (2020). Pengembangan Media E-Learning Berbasis Edmodo Pada Materi Teorema Pythagoras. AKSIOMA: Jurnal Program Studi Pendidikan Matematika, 9(4), 872-882. https://doi.org/https://doi.org/10.2 4127/ajpm.v9i4.3114

Firman, F., \& Rahayu, S. (2020). Pembelajaran Online di Tengah Pandemi Covid-19. Indonesian Journal of Educational Science (IJES), 2(2), 81-89. https://doi.org/10.31605/ijes.v2i2. 659

Gopal, A. D. O., \& Venugopal, V. 
DOI: https://doi.org/10.24127/ajpm.v100i2.3600

(2020). Students ' Readiness Towards Blended Learning in Era of Industrial Revolution ( IR ) 4 . 0. Journal of Advanced Research in Social and Behavioural Sciences, 21(1), 29-40.

Irfan, M., Kusumaningrum, B., Yulia, Y., \& Widodo, S. A. (2020). Challenges During the Pandemic: Use of E-Learning in Mathematics Learning in Higher Education. Infinity Journal, 9(2), 147-158.

https://doi.org/10.22460/infinity.v 9i2.p147-158

Jayalath, C., Wickramasinghe, U., Kottage, H., \& Somaratna, G. (2020). Factors Influencing Orderly Transition to Online Deliveries during COVID19 Pandemic Impact. Asian Journal of Education and Social Studies, 9(2), $10-24$. https://doi.org/10.9734/ajess/2020 /v9i230242

Kamsurya, R. (2020). Learning Evaluation of Mathematics during the Pandemic Period COVID-19 in Jakarta. International Journal of Pedagogical Development and Lifelong Learning, 1(2), 1-5. https://doi.org/10.30935/ijpdll/843 9

Kerres, M. (2020). Against All Odds: Education in Germany Coping with Covid-19. Postdigital Science and Education, 2(3), 690694.

https://doi.org/10.1007/s42438020-00130-7

Maharani, N. (2021). Analisis Kebutuhan Bahan Ajar Video Berbasis Pen Tablet Dalam Pembelajaran Topik Integral Selama Pandemi Covid-19. PENDIPA Journal of Science Education, 6(1), 41-48.
Mailizar, Almanthari, A., Maulina, S., \& Bruce, S. (2020). Secondary school mathematics teachers' views on e-learning implementation barriers during the COVID-19 pandemic: The case of Indonesia. Eurasia Journal of Mathematics, Science and Technology Education, 16(7), $1-9$. https://doi.org/10.29333/EJMSTE 18240

Mishra, L., Gupta, T., \& Shree, A. (2020). Online Teaching-Learning in Higher Education During Lockdown Period Of COVID-19 Pandemic. International Journal of Educational Research Open, 12(1). https://doi.org/10.1016/j.ijedro.20 20.100012

Mulenga, E. M., \& Marbán, J. M. (2020). Prospective Teachers' Online Learning Mathematics Activities in The Age Of COVID19: A Cluster Analysis Approach. Eurasia Journal of Mathematics, Science and Technology Education, 16(9). https://doi.org/10.29333/EJMSTE 18345

Nieuwoudt, J. E. (2020). Investigating Synchronous and Asynchronous Class Attendance As Predictors of Academic Success In Online Education. Australasian Journal of Educational Technology, 36(3), $15-25$. https://doi.org/10.14742/AJET.51 37

Nkansah, E., Ayiku, F., Mensah, Y. A., Nkrumah, C. F., \& Evans, A. (2020). COVID-19 Pandemic: Assessing the Effectiveness of Educational Technology Applications on Improvement of Tutor-student Relationships in 
DOI: https://doi.org/10.24127/ajpm.v100i2.3600

Ghanaian Colleges of Education. Asian Journal of Education and Social Studies, 10(3), 39-49. https://doi.org/10.9734/ajess/2020 /v10i330270

Peters, M. A., Wang, H., Ogunniran, M. O., Huang, Y., Green, B., Chunga, J. O., Quainoo, E. A., Ren, Z., Hollings, S., Mou, C., Khomera, S. W., Zhang, M., Zhou, S., Laimeche, A., Zheng, W., Xu, R., Jackson, L., \& Hayes, S. (2020). China's Internationalized Higher Education During Covid-19: Collective Student Autoethnography. Postdigital Science and Education, 2(3), 968988.

https://doi.org/10.1007/s42438020-00128-1

Radha, R., Mahalakshmi, K., Kumar, V. S., \& Saravanakumar, A. R. (2020). E-Learning during Lockdown of Covid-19 Pandemic: A Global Perspective. International Journal of Control and Automation, 13(4), 10881099.

Rahmawati, A. D., \& Khamid, A. (2020). The Impact of Online Lecture in The Covid-19 Pandemic Towards The Course Material Understanding (Explorative Study to Islamic Education Postgraduate Students ... Tarbiyah: Jurnal Ilmiah ..., 9(2), 108-115. http://jurnal.uinantasari.ac.id/index.php/jtjik/articl e/view/3677

Rusmini, R., Harahap, F. S. W., \& Guntoro, F. R. (2020). Analysis of The Role of Metacognition Based on Process Complex Problem Solving Against Mathematical Understanding of Statistics in The Era Pandemic COVID-19. Journal of Physics: Conference
Series, 1663(1). https://doi.org/10.1088/17426596/1663/1/012039

Saputro, B., Saerozi, M., \& Ardhiansyah, F. (2020). Philosophical Reflections: Critical Analysis of Learning Strategies for Science Practicum During the COVID-19 Pandemic. IJORER: International Journal of Recent Educational Research, 1(2), 7889.

https://doi.org/10.46245/ijorer.v1i 2.26

Septyanti, E., \& Kurniawan, O. (2020). Studi Eksploratif Kebutuhan Pembelajaran Daring untuk Mata Kuliah Menyimak pada Masa Pandemi Covid-19. Diglosia: Jurnal Kajian Bahasa ..., 3(4), 365-372.

http://diglosiaunmul.com/index.ph $\mathrm{p} /$ diglosia/article/view/106

Setiawan, A. (2019). Implementation of Islamic Education Study Program Learning Based on Blended Learning in the Industrial Era 4.0 at IAIN Samarinda. Dinamika Ilmu, 19(2), 305-321. https://doi.org/10.21093/di.v19i2. 1781

Sunhare, P., Chowdhary, R. R., \& Chattopadhyay, M. K. (2020). Internet of Things and Data Mining: An Application Oriented Survey. Journal of King Saud University - Computer and Information Sciences. https://doi.org/10.1016/j.jksuci.20 20.07.002

Sy, M., O’Leary, N., Nagraj, S., ElAwaisi, A., O'Carroll, V., \& Xyrichis, A. (2020). Doing interprofessional research in the COVID-19 era: a discussion paper. Journal of Interprofessional Care, 34(5), 
DOI: https://doi.org/10.24127/ajpm.v100i2.3600

600-606.

https://doi.org/10.1080/13561820. 2020.1791808

Tsitsia, B. Y., \& Kabbah, S. K. (2020). Trainee-Teachers' Perceptions on Traditional, Online And Hybrid Learning Modes of Mathematics Education in Ghana. African Journal of Education and Practice (AJEP), 6(7), 87-100.

Tsitsia, B. Y., Kabbah, S. K., Valence, D., \& Safo, P. (2020). Colleges of Education Student- Teachers , Perceptions on the E-Learning in the Era of Covid-19 Pandemic. European Journal of Education Studies, 7(12), 561-571. https://doi.org/10.46827/ejes.v7i1 2.3455

Verma, G., Campbell, T., Melville, W., \& Park, B. Y. (2020). Science Teacher Education in the Times of the COVID-19 Pandemic. Journal of Science Teacher Education, 31(5), 483-490. https://doi.org/10.1080/1046560X .2020 .1771514

Xu, W., \& Zammit, K. (2020). Applying Thematic Analysis to Education: A Hybrid Approach to Interpreting Data in Practitioner Research. International Journal of Qualitative Methods, 19, 1-9. https://doi.org/10.1177/16094069 20918810

Zaheer, M., \& Munir, S. (2020). Research supervision in distance learning: issues and challenges. Asian Association of Open Universities Journal, 15(1), 131143.

https://doi.org/10.1108/aaouj-012020-0003

Zhu, X., \& Liu, J. (2020). Education in and After Covid-19: Immediate Responses and Long-Term Visions. Postdigital Science and
Education, 2(3), 695-699. https://doi.org/10.1007/s42438020-00126-3

Zuriah, N., \& Rahmandani, F. (2021). Analysis of Online Learning Implementation and Student Learning Activities in the Covid19 Pandemic Era and Its Problems. Advances in Social Science, Education and Humanities Research, 524, 167176. https://doi.org/10.2991/assehr.k.2 10204.026 